Published in Catena, 2019, vol. 173, pp. 59-70,

\title{
Modelling the water balance on farming practices at plot scale: case study of Tougou watershed in Northern Burkina Faso
}

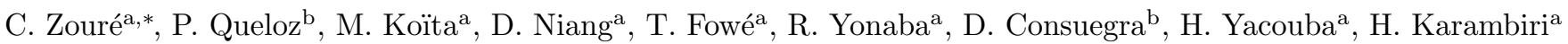 \\ ${ }^{a}$ Laboratory of Hydrology and Water Resources (LEAH), International Institute for Water and Evnironmental Engineering (2iE), \\ Ouagadougou, Burkina Faso \\ ${ }^{b}$ Institute of Territorial Engineering INSIT, School of Business and Engineering Vaud (HEIG-VD), University of Applied Sciences, \\ Yverdon-les-Bains, Switzerland
}

\begin{abstract}
In the Sahel region, farmers have adopted various farming practices to improve agricultural yields in order to offset an increasingly variable climate regime and the extension of degraded land. This study analyses the functional behaviour of such three selected water-harvesting techniques (stone rows, zaï and half-moon) as compared to the traditional tillage method through a comprehensive experimental setup monitored during three consecutive growing seasons (2015-2017). The results indicate that these farming practices allow a runoff reduction by 25 to $100 \%$. We propose a continuous model simulating the hydrological dynamics of the farming techniques at plot scale. This model is able to reproduce accurately the observed runoff $\left(R^{2}=0.73-0.95\right)$, and gives an insight of the variability of the water storage for each type of techniques in response to the rainfall regime. It appears in particular that zail and half-moons are able to mitigate the effect of dry spells by sustaining available water for crops over extended periods up to three weeks, whereas the direct seeding and stone row techniques rapidly leads to plant water deficit after five days. Even though water infiltration is essentially fostered by surface water retention during rainfall events, our observations suggest that the changes induced to the hydrological dynamics by farming practices also affect soil physical, chemical and biological properties. These effects help completing the explanation of crop yield improvements, but raise some questions of soil evolution and farming practice performances in the long run.
\end{abstract}

Keywords: Water harvesting techniques, Sahel, SCS-CN model, Water balance, Rainfall variability

\section{Introduction}

In the Sahel, agriculture is dominated by cereal-based cropping systems, which accounts for $97 \%$ of rainfed crops (Rockström et al., 2004). Low-income and difficult access to underground water restrict irrigation agriculture only in the close vicinity of the reservoirs, hence making each seasonal harvest essential for the subsistence of the local population. During the last decades, decreasing annual rainfall combined with growing anthropogenic pressures have accelerated soil degradation processes and increased the surface of barren land (Mahé and Paturel, 2009: Maisharou et al., 2015). This situation has led development partners to regain interest and improve traditional farming techniques, especially after the succession of dry years in 1972/73 and 1983/85 (Maisharou et al., 2015). The nature of these farming practices are as diverse as soil amendment, water harvesting, erosion control and mixed measures (e.g. assisted natural regeneration). These farming practices aim at providing more favourable conditions for vegetation development and gradually restore the natural functions of the soil by improving its physical and

\footnotetext{
*Corresponding author

Email address: oumar.zoure@2ie-edu.org (C. Zouré)
}

chemical properties. These practices have helped to rehabilitate 200 '000 to 300 '000 hectares of degraded land and produce $80^{\prime} 000$ tons of additional food per year in the central plateau of Burkina Faso (Reij et al., 2009). This explains the large adoption rate of farmers (more than 70\%) of at least one of these techniques (Zongo, 2016; Kpadonou et al. 2017).

Many scientific studies regarding farming practices are available, but they are mostly focused on cereal yield (Da, 2008: Danjuma and Mohammed, 2015), on their potentiel for soil restoration or on their impact on the local economic income (Zougmoré et al., 2005, Zongo, 2016). However, there is little literature on the changes induced by these practices on the water regime and hydrological processes (Duponnois and Dia, 2013). These techniques involve significant alterations of the surface topography, thus strongly affecting the hydrological dynamics by providing an intermediate retention volume, hence avoiding rapid losses through runoff and increasing infiltration. On the longer term, these changes in hydrodynamics also influence the soil properties, altering its physical, chemical and biological processes (Roose et al. 1995; Zougmoré et al. 2014). For example, limiting surface runoff does not only entail larger infiltration, but it also impedes the flushing of 
amendments and prevent sediment loss (Zougmoré et al. 2003a).

In order to assess the impact of the different farming techniques and the prevailing climatic regime on the water balance, modelling could be a valuable analysis tool as many processes are not easily measurable and the climate forcing cannot be controlled. For that matter, a continuous model is required, which encompasses recharge, transfer and discharge processes both during the intraand inter-events periods. Two-dimensional runoff models (based on the shallow water equations) have successfully simulated observed runoff dynamics on infiltrating surfaces at plot scale (Esteves et al. 2000; Fiedler and Ramirez, 2000, Mügler et al., 2011). However, such models are compute-intensive for complex geometries, which makes them unpractical for continuous simulations. In addition, they lack an explicit characterization of the soil water storage and are therefore difficult to combine with evapotranspiration models. Lumped or semi-distributed models, which implement simpler runoff schemes like the well-known GR-models (Perrin et al., 2009), KINEROS (Woolhiser et al. 1990) or SCS-CN method (United States Departement of Agriculture, 1986), are hardly appropriate at plot scale and in their original form. They cannot account explicitly for uneven surface microtopography that strongly affects surface runoff dynamics (especially combined with low-infiltrating soils), and are therefore usually unable to reproduce the complex interactions between surface runoff, ponding and infiltration at such scale.

In this study, we aim at understanding how the implementation of different farming practices affect the water balance at plot scale, and how the agricultural yield depends on the hydrological conditions and may be affected by water stress periods. For this purpose, an experimental setup combining four different water harvesting techniques was installed and extensive hydrological monitoring was performed during three consecutive years. As climate variability during rain seasons is high and the local perception seems to witness a shift of the rain season and a decrease in rainfall frequency, we also want to provide a tool that can predict the hydrological behaviour of each technique under different climatic forcing. A simple daily lumped model was developed and allows reproducing the observed runoff and simulating the other components of the water balance.

\section{Materials and methods}

\subsection{Study area}

The study area is the Tougou watershed $\left(13.65^{\circ} \mathrm{N}\right.$; $2.26^{\circ} \mathrm{E}$ ) located in the upper Nakambe River basin, Northeastern Burkina Faso. This site provides a representative study case regarding the issues raised, and has the advantage of being monitored since 2004. The Tougou watershed covers an area of $37 \mathrm{~km}^{2}$ (Figure 1). The climate is semi-arid with an average annual rainfall of $650 \mathrm{~mm}$ and temperature range between 18 to $40{ }^{\circ} \mathrm{C}$ during the period of 1961 to 2015 . The rainy season spans from June to September with the peak rainfall generally recorded in July or August. Soils are either cultivated (essentially during the rainy season) or bare (generally because of degradation) and the vegetation consists of savannah, shrubs and grasslands (Mounirou et al. 2012).

Since 1972, a significant decrease of natural vegetation, which covered then a fifth of the watershed area, has been observed, whereas the surface of bare soils has increased (Diello, 2007). A significant loss of fertility due to the impact of increasing runoff and erosion on these bare soils has been reported in this watershed (Mounirou et al., 2012, Maïga-Yaleu et al., 2013, 2016). This decrease of arable land combined with the scarce rainfall of the last decades has encouraged more than $60 \%$ of local farmers to adopt agricultural techniques (Barbier et al., 2009; Zongo et al. 2015). In the Tougou watershed, surveys have shown that farmers combine at least two farming practices (Barbier et al. 2009).

\subsection{Experimental design}

The experimental setup was installed on a bare soil that has been left uncultivated because of its productivity deficiency. The soil type is tropical ferruginous, leached with sediment and concretions (BUNASOLS, 2015) with an average slope of $1.33 \%$. The soil depth profile of $120 \mathrm{~cm}$ can be divided in three distinct layers (Table 1). An erosion surface crust was visually identified using the method described by Casenave and Valentin (1989).

The experimental setup consists of two replicates (A and B) of a complete Fisher random block (Jayaraman, 1999). The two blocks were set up on the same geomorphological unit (crust, slope, soil type). A block is composed of four identical plots $(20 \mathrm{~m}$ by $10 \mathrm{~m}$ ), except for the farming practice that was implemented on each (Figure 2). Each plot is isolated by corrugated iron sheets, vertically driven $30 \mathrm{~cm}$ into the soil. These sheets protrude $30 \mathrm{~cm}$ above the ground, preventing lateral surface runoff from one plot to the other. The plots have been designed following the recommendations of the Environmental Institute for Agricultural Research in Burkina Faso (Zougmoré and Zida, 2000a b; Zougmoré et al., 2000).

The water harvesting techniques implemented are those commonly used in the watershed (Barbier et al., 2009. Zongo, 2016): stone row (T1), half-moons (T2), zaï (T3) and direct seeding (T0) which represents the control (Figure 2. The farming practices were first implemented before the 2015 rainy season (July to October) and then rehabilitated at the same period in 2016 and 2017. The traditional direct sowing method in rows (with a small pickaxe called "daba") is practiced on the control plot. The zaï consists of excavated holes every $80 \mathrm{~cm}$ distributed in staggered rows, with a diameter of 20-40 $\mathrm{cm}$ and a depth of 10-15 cm (about 16000 holes per ha). The half-moons are staggered semi-circular excavations, with a diameter of $4 \mathrm{~m}$ and a depth of 15-25 $\mathrm{cm}$ (about 420 half-moons 


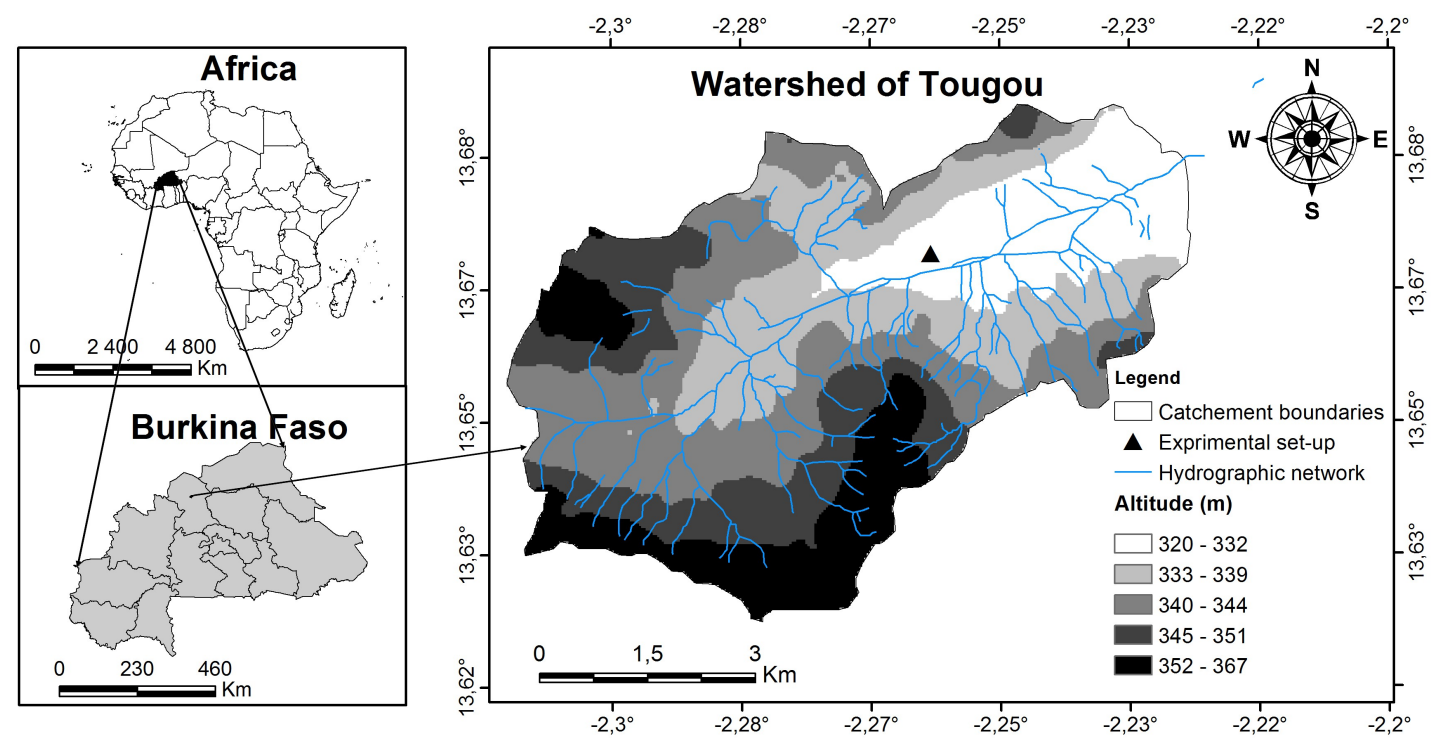

Figure 1: Location of the experimental site in Tougou watershed, Burkina Faso (data from National Topographic Digital Database, BNDT, 2002).

Table 1: Soil texture, field capacity (FC), wilting point (WP) and bulk density (BD) of the experimental site (BUNASOLS 2015).

\begin{tabular}{cccccccc}
\hline $\begin{array}{c}\text { Depth } \\
\mathrm{cm}\end{array}$ & $\begin{array}{c}\text { Textural class } \\
\text { (USDA) }\end{array}$ & $\begin{array}{c}\text { Clay } \\
\%\end{array}$ & $\begin{array}{c}\text { Silt } \\
\%\end{array}$ & $\begin{array}{c}\text { Sand } \\
\%\end{array}$ & $\begin{array}{c}\text { FC } \\
-\end{array}$ & $\begin{array}{c}\text { WP } \\
-\end{array}$ & $\begin{array}{c}\text { BD } \\
g / \mathrm{cm}^{3}\end{array}$ \\
\hline $0-22$ & Clay & 43 & 22 & 35 & 0.20 & 0.09 & 1.67 \\
$22-56$ & Clay loam & 35 & 22 & 43 & 0.20 & 0.10 & 1.67 \\
$56-83$ & Sandy clay loam & 31 & 18 & 51 & 0.18 & 0.09 & 1.7 \\
$83-120$ & Sandy clay loam & 31 & 18 & 51 & 0.19 & 0.09 & 1.74 \\
\hline
\end{tabular}

per ha). Two meters separate two half-moons on the same row, and the distance between the rows is $4 \mathrm{~m}$. The excavated material from the deeper layers is used to form a bulge around the half-circle on the downstream side, while shallower excavated material is mixed with animal manure and replaced in the half-moon. The stone row consists of a line of densely packed stones buried $15 \mathrm{~cm}$ in the ground, perpendicular to the streamflow. The stone row is $20-30$ $\mathrm{cm}$ high above the soil surface and $15-20 \mathrm{~cm}$ wide. In the $20 \mathrm{~m}$ long plot, only one stone row has been built $6 \mathrm{~m}$ upstream of the outlet (Figure 2). Pictures of the farming practices are shown in Figure 3 .

The crop planted on all plots is a variety of millet (IKMP5, nicknamed Kiipala). This crop has been introduced in Burkina Faso by INERA (Institut de l' Environnement et Recherches Agricoles, Burkina Faso) for its resistance to dry spells, its earliness and a relatively short development cycle (the late season starts 70 days after sowing, instead of 80 days for conventional millet), resulting in a wide adoption by local farmers. Sowing was conducted after the first showers announcing the onset of the rainy season at regular intervals of $60 \mathrm{~cm}$ on each plot except on zaï, where spacing were $80 \mathrm{~cm}$ and distributed in staggered rows. Manure and mineral fertilizer were supplied to each plot before sowing, following the usual recommendations in practice in this area. Animal manure consisting of cow dung was applied at a dose of $35 \mathrm{~kg}$ (a wheelbarrow) per half-moon; an equivalent rate of $900 \mathrm{~g}$ of manure was supplied per zaï hole, both rates resulting in a dose of $15 \mathrm{t} / \mathrm{ha}$ also supplied to the control and stone row plots. NPK (14-23-14, $100 \mathrm{~kg} / \mathrm{ha}$ ) was added after the first ploughing occuring 14 days after sowing. Urea $(46 \% \mathrm{~N}, 50 \mathrm{~kg} / \mathrm{ha})$ was added at two different dates: 30 days after sowing (corresponding to the second ploughing) and 56 days after sowing (Zougmoré et al., 2004, Sawadogo et al., 2008, INERA, 2011).

\subsection{Data collection and analysis}

Rainfall was recorded by an automatic rain gauge (RainLogger Gold, Solinst, Canada) and validated using rainfall depths measured with a manual rain gauge. Temperature, solar radiation, wind speed and direction, air humidity, dew point and relative humidity were recorded at an hourly-timestep with a WatchDog weather station (Spectrum Technologies Inc., USA) allowing the calculation of reference evapotranspiration using the Penman-Monteith 


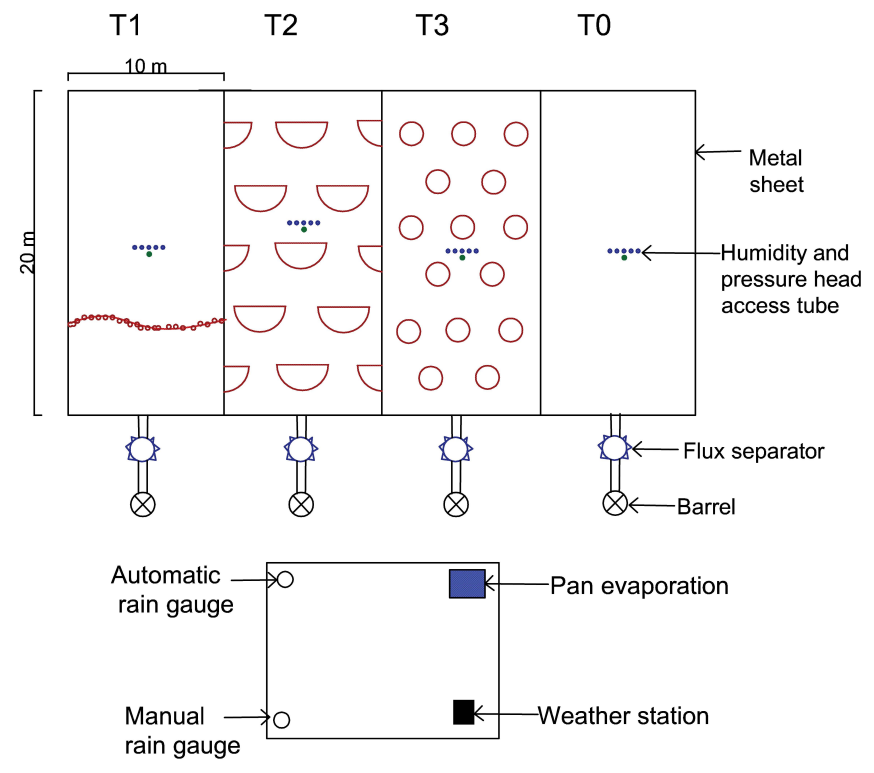

Figure 2: Design of the experimental plot at Tougou, Burkina Faso. Only one of two replicated blocks is represented: control plot (T0), stone row (T1), half-moons (T2) and zaï (T3). Note that half-moons and zaï are not represented at scale.

method (Allen et al. 1998). Daily evaporation was measured using a Colorado evaporation pan.

Runoff volumes were measured on each plot after each rainfall event. The outlet of each plot was connected to a circular $1 m$-diameter tank fitted with 40 holes (diameter of $30 \mathrm{~mm}$ ) drilled $500 \mathrm{~mm}$ above the bottom in the tank wall. A plastic pipe connected one of the hole to a buried 250litres barrel nearby. Total runoff volume was calculated by summing up the water volume of the circular tank and the volume of water in the barrel multiplied by the number of holes.

Volumetric moisture and pressure load were measured using a moisture sensor TDR (TRIME-PICO T3 / IPH44, SDEC France) and electronic tensiometer (SMS 2500S, SDEC France). Moisture and pressure head were recorded daily every $10 \mathrm{~cm}$, respectively $20 \mathrm{~cm}$ from ground level up to $100 \mathrm{~cm}$, respectively $120 \mathrm{~cm}$. A moisture access tube and 5 tensiometric rods were installed in the centre of each plot (i.e. outside of the zaï pocket or half-moon pound). Soil saturated hydraulic conductivity was measured using a double-ring infiltrometer (SDEC France), performing triplicate measurements at different locations on each plot (inside the zaï pits and half-moon ponds) before the onset of the 2015-, 2016- and 2017- rainy seasons. Infiltration test was carried out with a constant water head of $3 \mathrm{~cm}$ at the ground surface until reaching the steady infiltration rate. The saturated hydraulic conductivity corresponds to the asymptote of the infiltration curve (Niang et al. 2012 Keita et al. 2014). The drainage was estimated using Darcy's equation (Darcy, 1856) at the depth of $100 \mathrm{~cm}$ as the rooting depth for millet should not exceed this value (Allen et al. 1998). The daily measurement of pressure head at 80 and $120 \mathrm{~cm}$ and the determination of unsaturated hydraulic conductivity function at the depth of $100 \mathrm{~cm}$ were used for drainage estimation. Drainage was finally overlooked as the measurements revealed that no or negligible drainage occurs at this depth. In 2016 and 2017 , the experimental site was monitored during the complete rainfall season, i.e. from the date of seeding (2 July 2016 and 3 July 2017) to the date of harvest (16 October 2016 and 15 October 2017). In 2015, as the installation of the experimental setup was still ongoing when the rainy season set in, crop seeds were planted only on 15 July and measurements began on 10 August. Harvesting took place at the end of the rains on 12 October 2015, closing the season with a slightly shortened crop cycle.

\subsection{Modified SCS-CN method for continuous water bal- ance modelling}

The USDA National Resources Conservation Service (NRCS) agency, formerly known as the Soil Conservation Service (SCS), has developed the SCS-CN approach (Mishra and Singh, 2003) which has been widely used during the last decades, also in the Sahelian context (see e.g. Peugeot et al., 1997; Gerbaux et al., 2009, Assefa et al., 2016). This method allows to evaluate the partitioning of rainfall between hortonian overland flow and infiltration, which is supposed to be proportional to the degree of saturation of the soil, assuming a soil-specific storage capacity. The SCS-CN approach was initially developed for event-base modelling and therefore does not allow the consideration of specific initial conditions for different rainfall events. This limits the relevance of such a model in a context characterized by a large precipitation variability, because the initial soil water content can vary largely depending on the climatic conditions experienced ahead of a rainfall event. Another constraint of the SCS-CN method is that due to the lack of an explicit geometry, it cannot account in its original form for more complex surface processes than initial losses, which simply slice off the earliest part of the rainfall (and are therefore definitely lost for the hydrological system). In the present study, we propose two major amendments to the original SCSCN method in order to address the restraints critical to our case study. Firstly, as we aim at simulating the continuous hydrological fluxes during the entire rainy season and accounting for variable conditions at the onset of each rainfall event, the water storage needs to be continuously monitored. Its state relative to the maximum storage capacity can thus be used to determine the partitioning between runoff and infiltration when a rainfall event starts. This can be done by tracking incoming and outgoing fluxes of the soil, essentially infiltration and evapotranspiration. Secondly, another modification has been done to encompass more complex surface retention/detention processes induced by the layout of the water harvesting techniques. Even if the rainfall or intercepted-runoff water that ponds in the hollows on the soil surface could be viewed as initial 

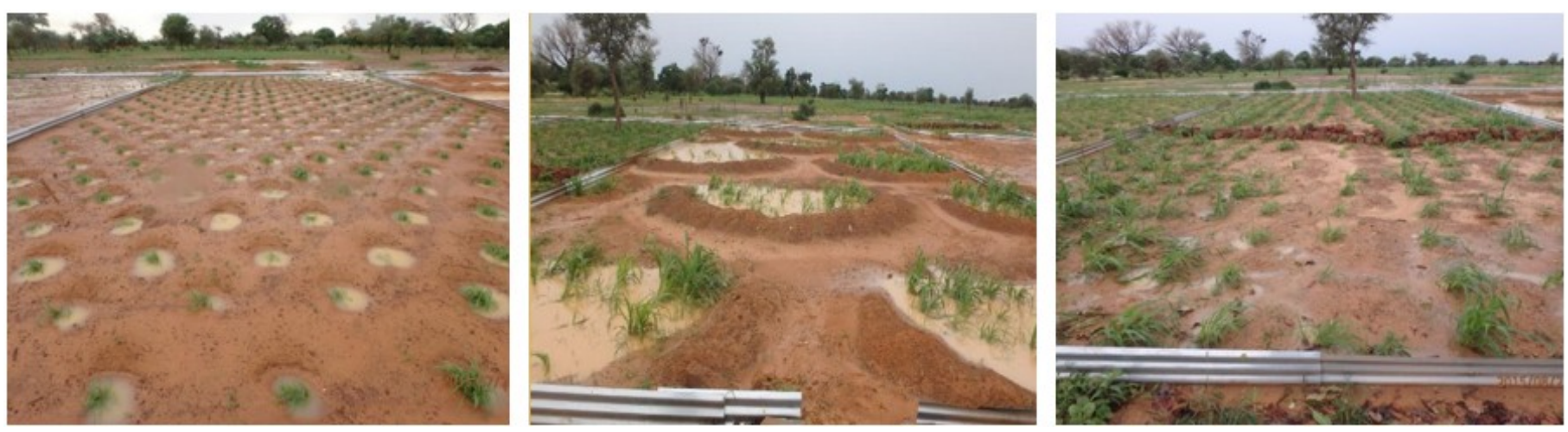

Figure 3: Pictures of the farming practices at the beginning of the rainy season (28 July 2015): zaï (left), half-moons (center) and stone row (right).

losses according to the original SCS-CN approach (runoff is triggered once these depressions are filled), this would represent an understatement in continuous simulation. Indeed, the water stored in the hollows is partly evaporated and infiltrated over a period that could persist even after rainfall event, depending on evaporation dynamics and soil infiltration capacity. This infiltration of ponding water also needs to be accounted for in the water storage. A schematic of the model is shown in Figure 4

When a rainfall event starts, the water will first completely fill the surface storage $\left(I_{a}=I_{a, \max }\right)$ before effective rainfall $P_{e f f}$ is generated. $P_{\text {eff }}$ is then partitioned between runoff production $R$ (Eq. 1) and direct infiltration $F_{a}$ (Eq. 2) depending on the subsurface storage current

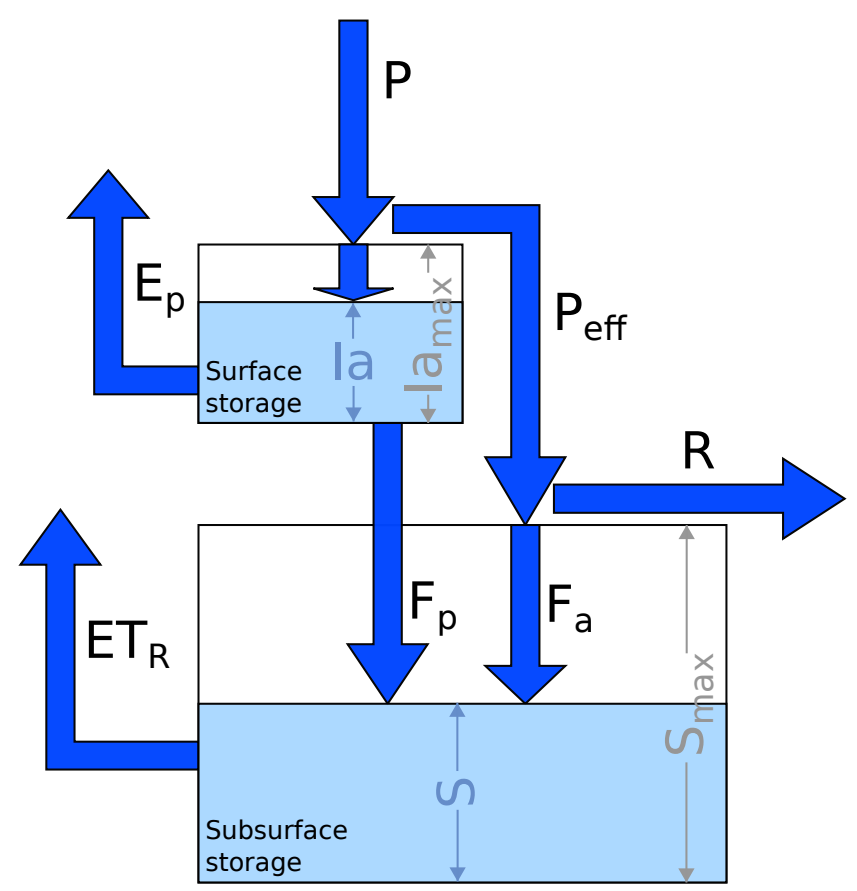

Figure 4: Schematic representation of the processes in the conceptual model. state (Mishra and Singh, 2003):

$$
\begin{gathered}
R=\frac{P_{e f f}^{2}}{P_{e f f}+\left(S_{\max }-S\right)} \\
F_{a}=P_{e f f}-R
\end{gathered}
$$

with $S_{\max }$ the maximum storage capacity and $S$ the actual storage, expressed in $\mathrm{mm}$. As the model is operated at a daily timestep, all other terms are expressed in $\mathrm{mm} / \mathrm{d}$. The difference $S_{\max }-S$ corresponds to the storage capacity (usually also termed $S$ ) in the conventional SCS-CN approach. Note that Eq. 1 stems from the empirical relationship between the cumulative infiltration over the soil storage capacity and the actual cumulative runoff over the potential maximum runoff $\left(P-I_{a}\right)$ that constitutes the basis of the SCS-CN method. In contrast to the conventional method, runoff is recalculated here at each time step using the current value of storage. This storage is thus also recalculated at each timestep by accounting for the incoming fluxes (namely direct infiltration $F_{a}$, and pond infiltration $F_{p}$ ) and outgoing flux (namely actual evapotranspiration $E T_{R}$ ). This allows to run the model in continuous mode.

The slow draining of ponding water into the subsurface is supposed to operate at a constant rate equal to the soil saturated hydraulic conductivity measured on each plot until the surface storage runs empty. Simultaneously to pond infiltration, free surface evaporation $E_{p}$ also draws water from the surface storage as long as water is available. Surface evaporation rates are calculated from the measurements of the evaporation pan.

Finally, actual evapotranspiration $E T_{R}$ uptakes water from the subsurface storage $S$, and therefore contributes to restore the storage capacity $S_{\max }$ (in $m m$ ) during interevent periods. The FAO-56 Penman-Monteith method (Allen et al., 1998) has been used to calculate the reference evapotranspiration $E T_{0}$ with the data of the weather station. Crop evapotranspiration $\left(E T_{C}\right)$ is further calculated by Eq. 3 and accounts for the crop-specific water requirements that depend on the development stage. The layout of the different water harvesting techniques considerably changes the effective plant density on the plot, as 
the spaces between the hollows are left unplanted. Hence, the equation for crop evapotranspiration reads:

$$
E T_{C}=K_{A} K_{C} \cdot E T_{0}
$$

with $E T_{C}$ and $E T_{0}$ in $m m / d$, and $K_{C}$ the unitless crop coefficient for millet, and $K_{A}$ a unitless plant density correction factor (Table 2). The model assumes that actual evapotranspiration $\left(E T_{R}\right)$ operates at its maximum rate $E T_{C}$ as long as water is available in the soil, i.e. as long as the soil water storage $S$ is able to supply the demand (Eq. 4) as suggested by Allen et al. (1998):

$$
\left\{\begin{array}{lll}
E T_{R}=E T_{C} & \text { if } & S \geq E T_{C} \\
E T_{R}=S & \text { if } & 0 \leq S<E T_{C}
\end{array}\right.
$$

The surface storage and subsurface storage were considered completely empty at the beginning of the rainfall season, as a long dry period usually precedes the onset of the season. Note that the condition of $S=0$ does not necessarily imply a completely dry soil physically speaking, but rather a state where no more water can be withdrawn by evapotranspiration (corresponding to the wilting point in soil science terms) and consequently not subject to a further decrease of soil water content in natural conditions. Given the sparse requirements of the SCS-CN method in terms of parameters and the comprehensive experimental measurement setup carried out, calibration can be relatively straightforward and does not require the use of optimization algorithm. For each farming practice, $I_{a, \max }$ and $S_{\max }$ need to be defined. As $I_{a, \max }$ represents the threshold above which runoff is generated, or the minimum rainfall volume to produce runoff (if $I_{a}$ is zero before rainfall starts), it can be directly evaluated from the rainfall-runoff experimental data. We have also assumed that the different agricultural techniques can affect the storage functions of the soil, therefore the maximum storage capacity $S_{\max }$ can be different for each technique. Thus, only $S_{\max }$ is calibrated for each technique in order to obtain the best agreement between observed and simulated runoff, as well as to increase the coefficient of determination. The other constant parameters used in the model are summarized in Table 2 .

\subsection{Statistics and model evaluation}

A statistical Pearson's correlation test was performed using XLSTAT 2016 version to inspect the homogeneity of runoff means across replicates for pairs of identical farming practices. A Fisher test was used to estimate the equality of variances. Distribution plots (P-P plot and Q-Q plot) and normality tests (Shapiro-Wilk, Aderson-Darling and Jarque-Bera) were used for assessing the normality of the data (Ghasemi and Zahediasl, 2012), and Kruskal-Wallis test was conducted to determine if the runoff data are significantly different between the four treatments. The
$5 \%$ confidence level was considered to determine statistical significance. The model performance for runoff prediction was assessed using the coefficient of determination $R^{2}$ (Moriasi et al., 2007, Foglia et al., 2009).

\section{Results}

\subsection{Field experiments}

Rainfall and runoff volumes were measured for each rainfall event during three consecutive crop growing seasons in 2015, 2016 and 2017. Seasonal rainfall and runoff statistics are summarized in Table 3. The recorded rainfall amounts during the three consecutive rainy seasons of 2015, 2016 and 2017 were $648 \mathrm{~mm}$ (29 events), $424 \mathrm{~mm}$ (33 events) and $397 \mathrm{~mm}$ (34 events), respectively. Most of the rainfall amount has fallen at the beginning of the season, from July to August, which represents $80 \%$ of total rainfall. In 2015, four extreme events were observed (50, 54, 68 and $124 \mathrm{~mm}$ ), whereas only one extreme event of $59 \mathrm{~mm}$ was observed in 2017. In 2016, all events were less than $50 \mathrm{~mm}$. The rainfall was more evenly distributed in 2015 compared to 2016 and 2017, with event inter-arrival time always shorter than a week. In contrast, three successive periods of 12-14 days without significant rainfall event (greater than $2 \mathrm{~mm}$, the minimum daily evaporation) were observed in September and October 2016 (millet mid-season and late season). In 2017, two periods of 11 and 23 days in July and October 2017 (millet development and late season) occurred.

Runoff measurements were available from the second half of the 2015 rainy season (10 August) and for the entire 2016 and 2017 rainy seasons. No significant difference between block A and block B for a same treatment was revealed by the Pearson's correlation test. Coefficient of determination were consistently strong, with $R^{2}$ values above 0.9 except for half-moons $\left(R^{2}=0.73-095\right.$, because of a much lower amount of runoff events observed) which indicates that the block A and B replicates were highly similar in terms of runoff production. Yet, the Kruskal-Wallis test at 5\%-significance level (with Dunn's pair comparison test) showed significant differences when comparing zaï and half-moons with the control ( $p$-values $<0.0001)$, but not between stone-row and the control $(p-$ value $=0.072)$. Hence, and for the sake of conciseness, we will only refer to block $\mathrm{A}$ in the following. Figure 5 shows the distribution of runoff event volumes of each farming practice during the crop growing seasons from 2015 to 2017. Median runoff is reduced from $8.4 \mathrm{~mm}$ for the control plot to $4.3 \mathrm{~mm}$ for the stone row and $2.1 \mathrm{~mm}$ for the zaï. Runoff was found to be very low (volumes below $0.7 \mathrm{~mm}$ ) on half-moon plots for rainfall events below $50 \mathrm{~mm}$. As compared to the control plot, cumulative runoff values of the growing seasons 2016 and 2017 were reduced by a factor of $24-39 \%$ for the stone row, 50-56\% for the zaï and 95-97\% for the half-moons (Table 3). It can be noticed that in 2015, runoff reduction factor of all techniques, but in particular stone row 
Table 2: Description of the state-independent parameters and their values for each farming practice.

\begin{tabular}{|c|c|c|c|c|c|c|}
\hline & Unit & Description & Control & Stone row & Zaï & Half-moons \\
\hline$K_{\text {sat }}$ & $\mathrm{cm} / \mathrm{h}$ & $\begin{array}{l}\text { Saturated hydraulic } \\
\text { conductivity }\end{array}$ & 3.4 & 3.8 & 6.4 & 1.0 \\
\hline$A_{P}$ & - & $\begin{array}{l}\text { Fraction of depression area } \\
\text { over total plot surface }\end{array}$ & 1 & 1 & 0.2 & 0.28 \\
\hline$d_{P}$ & plants/ha & Areal plant density & 24200 & 24200 & 16350 & 12600 \\
\hline$K_{A}$ & - & Plant density correction factor & 1 & 1 & 0.68 & 0.52 \\
\hline$K_{C}$ & - & Crop coefficent (Allen et al., 1998) & \multirow{2}{*}{\multicolumn{4}{|c|}{0.3}} \\
\hline & & Initial (day 0-14) & & & & \\
\hline & & Development (day 15-39) & \multicolumn{4}{|c|}{$0.3-1.0^{1}$} \\
\hline & & Mid-season (day 40-79) & \multicolumn{4}{|c|}{1.0} \\
\hline & & Late-season (day 80-104) & \multicolumn{4}{|c|}{$1.0-0.3^{2}$} \\
\hline & & After-season (from day 105) & \multicolumn{4}{|c|}{0.3} \\
\hline
\end{tabular}

${ }^{1}$ A linear increase between day 15 and day 39 is considered.

2 A linear decrease between day 80 and day 104 is considered.

and zaï, are much lower than for the following years. This can be explained by the occurrence of larger rainfall events observed during a shorter monitored period in 2015 (more than $25 \mathrm{~mm}$ were measured for 4 out of 9 events) that have triggered especially large amount of runoff. In addition, the efficiency of cultural practices has been shown to increase with time after their installation, which could also explain the higher runoff reduction observed in 2016 and 2017 (Roose et al., 1995, Zougmoré et al., 2014).

Saturated hydraulic conductivity measurements were conducted on each plot before the onset of the rainy season 2015, 2016 and 2017 (i.e. on dry soils). They are shown in Table 4. Before the rainy season of 2015, the values of

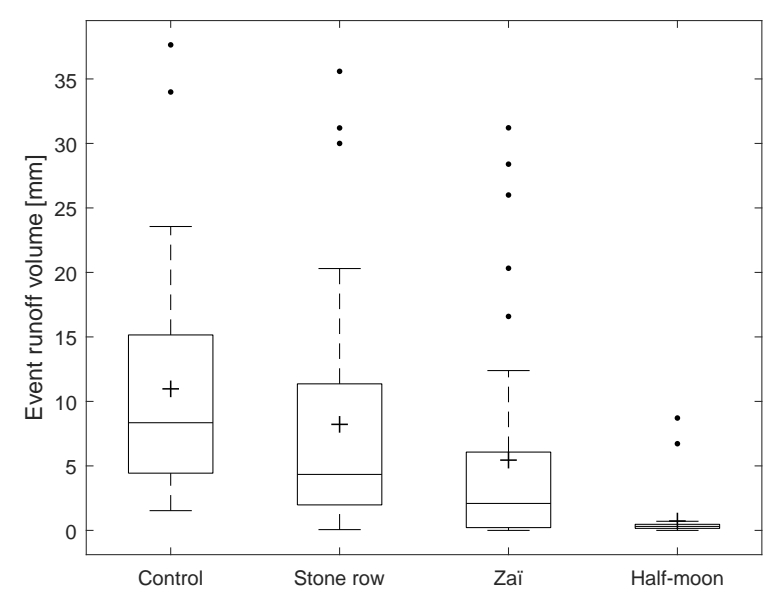

Figure 5: Box plots of the event runoff volume for 2015, 2016 and 2017 combined (36 events). The box's upper and lower edges represent the $25 \%$ - and $75 \%$-quartile. The middle line is the median and the + symbol the mean. The whiskers extend up to the last value smaller (respectively larger) than the third (respectively first) quartile plus 1.5 times the interquartile distance. The dots represent all the data out of the range defined by the whiskers. hydraulic conductivities were similar for the control, stone row, zaï and half-moon plots (around $4.2 \mathrm{~cm} / \mathrm{h}$ ) as the plots were installed on the same soil with no prior agricultural techniques. However, hydraulic conductivities have likely been impacted by the farming practices reinstalled during the two following seasons 2016 and 2017, as their values show an increase in the zaï pits $(7.2 \mathrm{~cm} / \mathrm{h}$ in 2017$)$, compared to the control and stone row plots where hydraulic conductivities have not changed significantly (4.7 and $3.5 \mathrm{~cm} / \mathrm{h}$ in 2017, respectively). In contrast, saturated hydraulic conductivity in half-moons has considerably decreased as low as about $1.1 \mathrm{~cm} / \mathrm{h}$.

Daily measurements of soil moisture profiles on each plot throughout the rainy season also depict some influence of the farming practices on infiltration dynamics (Figure 6). On the control plot, soil moisture varied between 10 and $23 \%$, but this variation was limited to a depth of $50 \mathrm{~cm}$. On the zaï and stone row plots, the wetting front depth reached $80 \mathrm{~cm}$ illustrating an enhanced infiltration capability, with higher soil moisture values between 20-60 $\mathrm{cm}$ below the soil surface. In the half-moon plot, the evolution of soil moisture profiles was different, with a strongly reduced variability at the surface and at shallow depths, but with a slightly larger variability beyond $60 \mathrm{~cm}$. Note that the profiles are not directly measured inside the hollows, but between the rows. Hence, it has been observed that half-moons have very limited impact on soil moisture if not directly under a pond. As the hydraulic conductivity is low and the ponds are widely spaced, lateral transfer is not significant, and a soil profile measured between two half-moon may be much drier than a profile measured below a pond. The key mechanism of half moons reside in their ability to retain important volumes of intercepted surface runoff in the ponds, which infiltrate slowly, but for extended durations. This provides a more constant and consistent water supply to the soil that can therefore reach deeper soil depths. 
Table 3: Characteristics of rainfall and runoff measured during the 2015-2017 crop growing seasons at the experimental plots. The longest inter-arrival time refers to the number of consecutive days without any significant single rainfall event (higher than $2 \mathrm{~mm} / \mathrm{d}$ ). Cumulative runoff represents the mean of block A and B (standard deviation in brackets) of the total runoff volume measured during a growing season for the same cultural practice.

\begin{tabular}{|c|c|c|c|c|}
\hline & & 2015 & 2016 & 2017 \\
\hline \multicolumn{2}{|c|}{ Number of rainfall events (of which runoff monitored) } & $29(9)$ & $33(33)$ & $34(34)$ \\
\hline \multicolumn{2}{|c|}{ Number of rainfall events $>50 \mathrm{~mm}$} & 4 & - & 1 \\
\hline \multicolumn{2}{|l|}{ Cumulative rainfall $[\mathrm{mm}]$} & 648 & 424 & 397 \\
\hline \multicolumn{2}{|l|}{ Longest inter-arrival time [days] } & 6 & 14 & 23 \\
\hline Cumulative runoff $[\mathrm{mm}]$ & $\begin{array}{l}\text { Control } \\
\text { Stone row } \\
\text { Zaï } \\
\text { Half-moon }\end{array}$ & $\begin{array}{r}108.7( \pm 11.4) \\
103.8( \pm 12.1) \\
78.3( \pm 12.2) \\
16.3( \pm 3.0)\end{array}$ & $\begin{array}{r}131.9( \pm 6.7) \\
81.5( \pm 5.9) \\
58.1( \pm 5.5) \\
4.9( \pm 0.2)\end{array}$ & $\begin{array}{r}123.7( \pm 9.3) \\
94.0( \pm 8.1) \\
61.6( \pm 8.4) \\
5.9( \pm 0.6)\end{array}$ \\
\hline $\begin{array}{l}\text { Runoff reduction factor (relative to the } \\
\text { control plot) }\end{array}$ & $\begin{array}{l}\text { Stone row } \\
\text { Zaï } \\
\text { Half-moon }\end{array}$ & $\begin{array}{r}4.5 \% \\
27.9 \% \\
85.0 \%\end{array}$ & $\begin{array}{l}38.2 \% \\
56.0 \% \\
96.3 \%\end{array}$ & $\begin{array}{l}24.0 \% \\
50.2 \% \\
95.3 \%\end{array}$ \\
\hline
\end{tabular}

Table 4: Mean and standard deviations of the saturated hydraulic conductivity measured on the experimental plots in April 2015, 2016 and 2017.

\begin{tabular}{lccc}
\hline$K_{\text {sat }}[\mathrm{cm} / \mathrm{h}]$ & 2015 & 2016 & 2017 \\
\hline Control & $4.0( \pm 0.7)$ & $3.4( \pm 0.5)$ & $4.7( \pm 0.6)$ \\
Stone row & $4.3( \pm 0.9)$ & $3.8( \pm 0.9)$ & $3.5( \pm 0.1)$ \\
Zaï & $4.5( \pm 0.3)$ & $6.4( \pm 0.4)$ & $7.2( \pm 1.1)$ \\
Half-moon & $3.9( \pm 0.2)$ & $1.1( \pm 0.3)$ & $1.2( \pm 0.4)$ \\
\hline
\end{tabular}
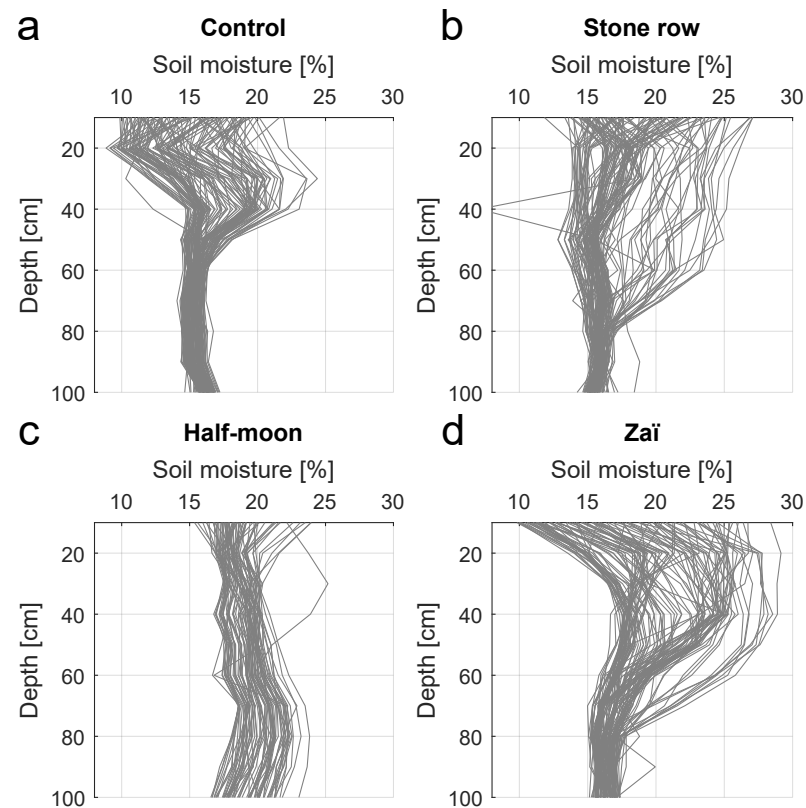

d

Zaï

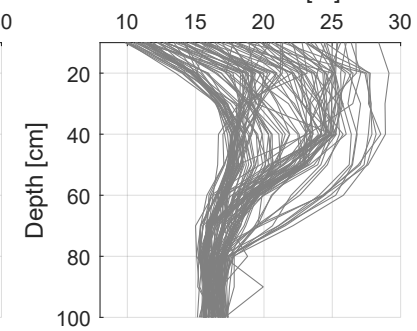

Figure 6: Overview of the temporal evolution of water profiles for each type of farming practice. Each grey line represents the soil moisture profile from ground level to $1 \mathrm{~m}$ depth measured on a specific day during the 2016 rainy season (block A). The profiles were measured between the rows of zaï and half-moons (and $1 \mathrm{~m}$ upstream of the stone row) and may not be representative of the profiles that would be observed under the hollows of zaï and half-moons (or farther from the stone row).

\subsection{Model parameters optimization for runoff simulation}

The model was calibrated with the 2016 observed runoff data using the parameters presented in Table 2. The two main technique-specific parameters for the modified SCSCN model are surface storage capacity $I_{a, \max }$ and maximum storage capacity $S_{\max }$. As the model assumes that surface storage must be completely filled before infiltration and runoff can be produced (section 2.4), $I_{a, \max }$ can be set to the precipitation threshold that should be exceeded to trigger runoff. This threshold is directly deducted from the observations as the smaller precipitation volume among all recorded events in 2016 that generates a significant runoff. Hence, the values used were 7, 10, 20 and $50 \mathrm{~mm}$ for control, stone row, zaï and half-moon plots respectively (see section 3.1. Our previous observations suggest that farming practices increase hydrodynamic properties of the soil surface, promoting a higher infiltration and sustaining an improved soil water storage. Hence, Smax has been calibrated independently for each farming practice in order to provide the best agreement between observed and simulated runoff volumes (see section 2.4). Calibrated values for $S_{\max }$ were 35,40 and $70 \mathrm{~mm}$ for control, stone row and zaï respectively. As half-moon plots have not generated any sizable runoff event, calibration and validation were not possible. It has thus been assumed a maximum storage $S_{\max }$ value of $70 \mathrm{~mm}$, corresponding to the largest storage capacity observed among the other plots. Figure $7 \mathrm{~b}$ shows the rainfall timeseries and the observed and simulated runoff response for each agricultural practice. It can observed that both the occurrence of runoff events and their magnitude are adequately reproduced, and the variability among the practices is closely grasped by the model. Observed runoff and climate data from the 2015 and 2017 campaigns were used for model validation using the same parameters as for 2016. The 2017 simulations also perform satisfactorily, with a good predictability of runoff occurrence and volumes for the three practices $\left(R^{2}\right.$ varies between 0.87 and 0.95 ). The 2015 simulations are 
represented in Figure 7 . They are also accurate, albeit the season has been much wetter than in 2016 and 2017 with intense rainfall events and large runoff volumes (note the different rainfall and runoff scales between 2015 and 2017 in Figure 7).

\subsection{Effect of farming practices on soil water storage and dry spell mitigation}

Besides simulating runoff, the modified SCS-CN model can be used to evaluate the impact of farming practices on the soil water dynamics, because the model is continuous and accounts for storage recharge and uptake. Figure 8 shows the state of the soil water storage for the three consecutive years and each farming practice. Overall, soil water storage (SWS) is higher for half-moons, followed by zaï, stone row and finally the control plot, which endorses the differences in runoff generation observed earlier. In 2015, the abundant and well-distributed rainfall has allowed sustaining the SWS throughout the season for all plot types (Figure 8a). Thus, evapotranspiration has not been limited at any time. This suggests that the hydrological requirements were met this year, even without the aid of a farming practice. The situation was different in 2016, as rainfall was sparse and unevenly distributed throughout the second half of the rainy season as opposed to year 2015 (Figure 8p). The SWS of the control and stone row plots have run dry four times and three times respectively, preventing water uptake from the crop. The three last dry spells $(65,77,93$ days after sowing, DAS) may have been particularly harmful for the yields because they lasted for more than a week. In contrast, the zaï and half-moon plots have been able to store enough water to overcome these dry spells and provide enough water for the plants. In total, the control plot and the stone row plot have faced 35 and 31 days (respectively) with dry storage, resulting in a plant water deficit over the season of $117 \mathrm{~mm}$ (respectively $105 \mathrm{~mm}$ ). During 2017, the SWS could not be fully replenished early in the season like in 2015 and 2016 due to limited rainfall at this time, as shown in Figure 8c. As such, SWS of all practices was low until 30-40 DAS and even occasionally dried up for short periods in the control plot. Still in the same year, right after the SWS of all plots was at full capacity (just before 40 DAS), short dry spells occurred, resulting in two small rainfall events of less than $5 \mathrm{~mm}$ in 11 days. As a consequence, the higher storage capacity combined to a smaller evapotranspiration demand on half-moon and the zaï plots (with respect to their smaller crop density) prevented the SWS from drying up for a longer period than the control and stone row plots, as pictured in Figure 8s. This period has led to a water shortage of one day only for the control plot, after which abundant rainfall has fully replenished the SWS of all plots. Very sparse precipitation occurred during the late season (after 75 DAS), inducing the complete dry up of the control and stone row storage during 16 and 14 days (respectively) until the harvest. In 2017, zaï and halfmoon techniques were again able to mitigate efficiently the effects of rain scarcity and losses through surface runoff. The control and stone row plots have experienced 25 and 17 days (respectively) of water shortage leading to a total plant water deficit of 58 and $44 \mathrm{~mm}$ (respectively).

Figure 9 compares the amount of time (fraction of the total duration of the season) during which a given value of SWC has been exceeded among the farming practices and between 2015 and 2016. The distribution of the SWS were very different between the two seasons: in 2015, the SWS was filled beyond half-capacity during almost $90 \%$ of the season for all plots, whereas half-capacity was exceeded during less than $40 \%$ of the time (for control and stone row) to $70 \%$ of the time (for half-moon). Moreover, the SWS was never totally emptied for any technique in 2015. Dry storage had occurred during about $30 \%$ of the crop season in the control and stone row plots in 2016, whereas zaï and half-moons have undergone low storage periods, but have barely dried up completely. This demonstrates the efficiency of agricultural techniques (in particular zaï and half-moons) in maintaining available water in the storage to overcome dry spells, but it also shows the sensitivity of these complex hydrological systems to the climatic forcing.

\section{Discussion}

The good performance of the model at reproducing observed runoff during of the calibration (2016) and validation datasets (2015 and 2017) can be attributed to its ability to grasp the different dynamics of the relevant hydrological processes that characterized each type of plot configuration. In particular, the amendments provided to the original SCS-CN method allows to account explicitly for a surface storage that mimics the retention of water in puddles shaped by the different types of agricultural practices. These large differences of surface retention capacities are responsible for a great part of the runoff variability observed. It should be reminded that the surface retention capacity parameter $\left(I_{a, \max }\right)$ is not calibrated but directly derived from the rainfall-runoff data. Their respective values for the zaï and half-moon plots can also be retrieved by calculating the total volume of the depressions divided by the plot surface. This demonstrates the physical and measurable interpretation of this parameter, which would support the relevance of the model as a predictive tool to simulate the effect of different geometries of the farming practices (as long as the total volume of the depression storage can be easily measured or estimated). It should be emphasized that the model assumes the complete filling of the surface storage before direct infiltration and runoff are triggered. Even if this surface storage has a similar effect as the initial abstraction defined by the conventional SCS-CN method, this surface storage later actively contributes to the recharge of the subsurface storage unlike initial abstraction. The magnitude and the dynamics of this recharge is driven by evaporation and pond infiltration rates, allowing potentially its extent over several days after 


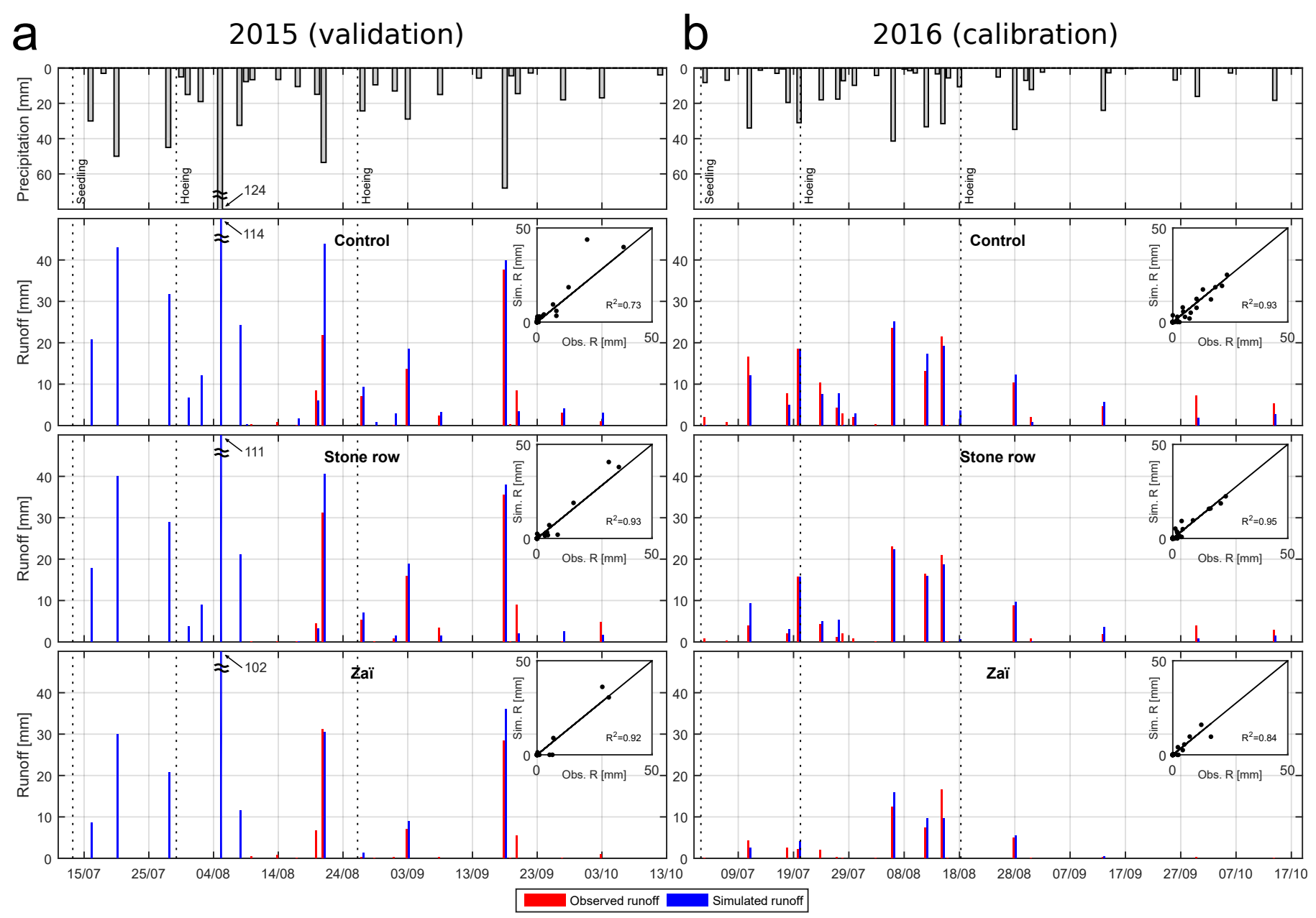

Figure 7: Observed and simulated runoff in 2015 (validation period) and 2016 (calibration period). Only the control plot, stone row and zaï are represented, as no runoff was observed on half-moons. The insets illustrate the correspondence between observed and simulated runoff and indicate the goodness of fit. Note that in 2015, runoff was measured only since 10 August. Data from 2017 are not represented here, as the rainfall regime and runoff responses were similar to 2016. 
a

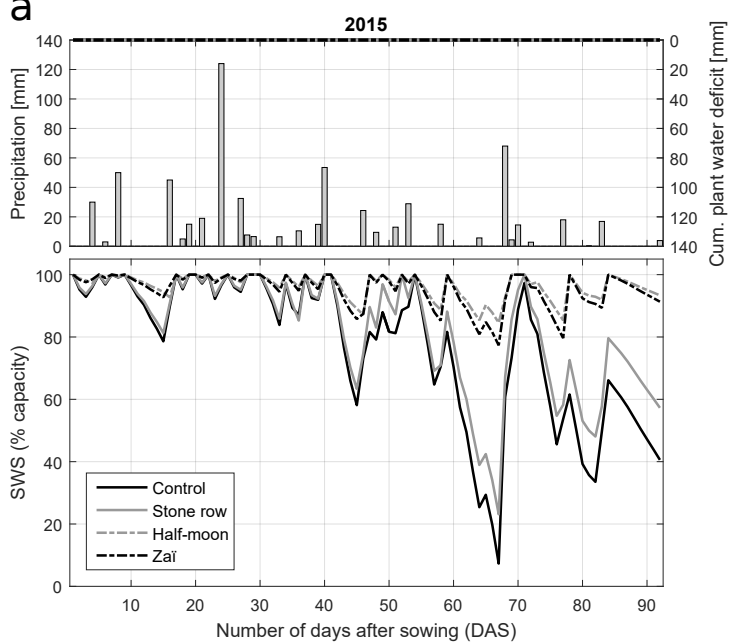

$\mathrm{b}$
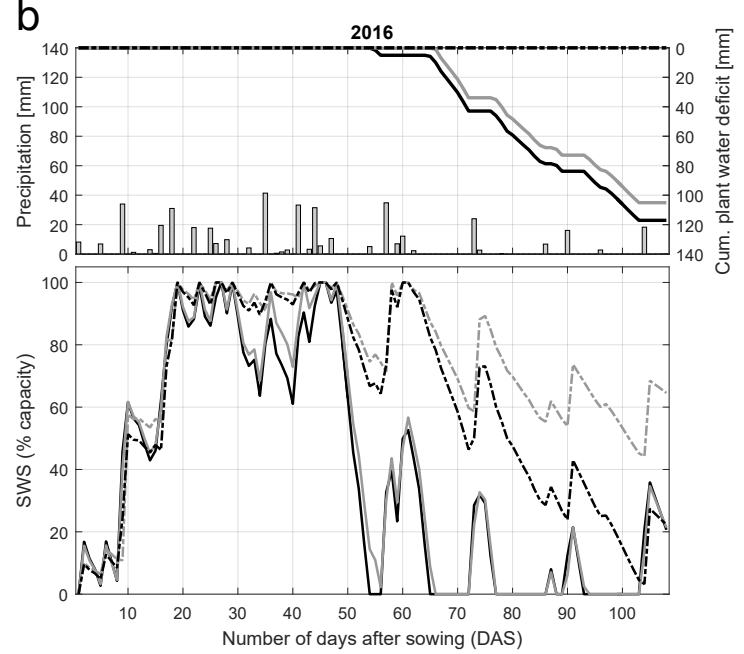

C

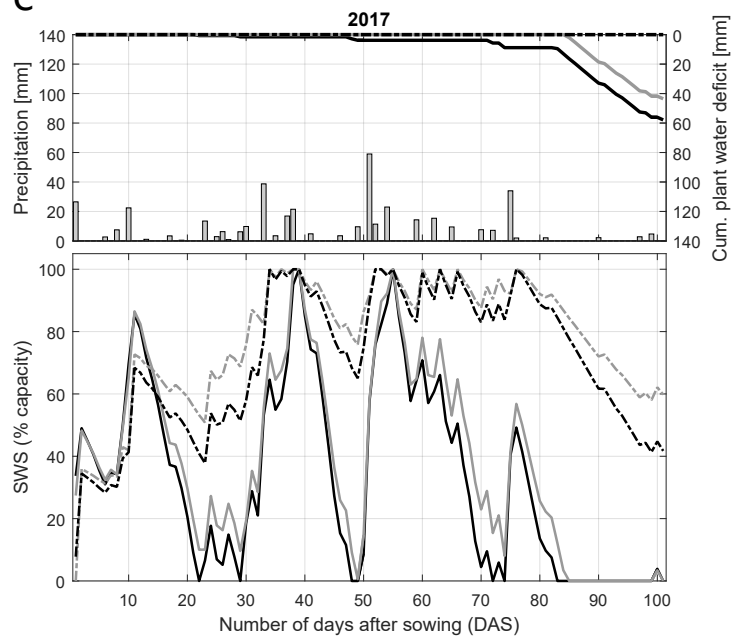

Figure 8: Evolution of rainfall and modelled soil water storage during the rainy season 2015 (a), 2016 (b) and 2017 (c) for the control, stone row, zaï and half-moons. The curves on top of the precipitation bars represent the cumulative plant water deficit, i.e. the difference between the cumulative crop evapotranspiration and the cumulative actual evapotranspiration.
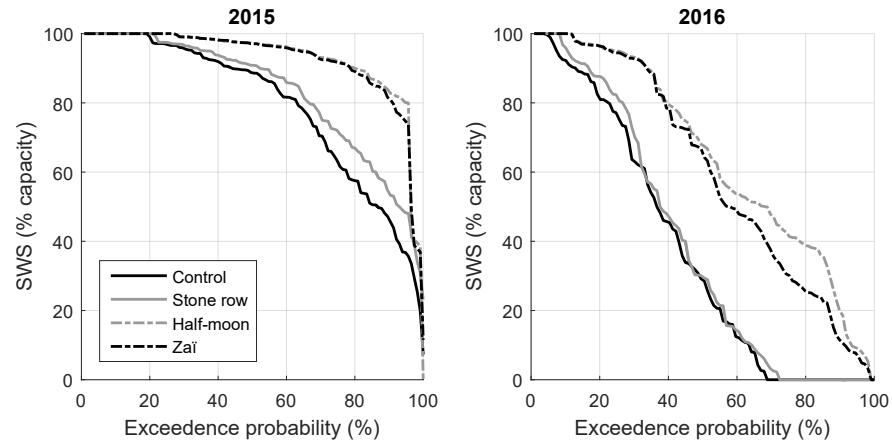

Figure 9: Exceedance probability of soil water storage in 2015 and 2016 for the four plot types. The exceedance probability curves for 2017 (not represented) are very similar to 2016.

the end of a rainfall event for some cases (like half-moons). The accounting of these processes allows the prediction of the specific soil moisture conditions prevailing before each rain event, which highly contributes to the capability of the model at reproducing the variability of runoff volumes. The saturated hydraulic conductivities measured on each plot were used as pond infiltration rates. These values seem to be overestimated, as the model did not show the persistence of water in the surface storage for more than one day, whereas field observations have demonstrated occasional water stagnation during up to four days in the half-moons. However, this situation does not have noticeable effect on the simulations presented here, because only half-moons have demonstrated water retention on longer timescales than one day while the model works at the daily timestep. Hence, for the other techniques, overestimation of pond infiltration does not change the overall dynamics of surface water, but only the partitioning of surface water between evaporation and infiltration (however only to a negligible extent). For half-moons, the overestimation of pond infiltration rate may lead to the underestimation of evaporation fraction in favour of infiltration, therefore unduly inflating the subsurface storage. This could not be evaluated as virtually no runoff has been observed on half-moon plots.

The different values of $S_{\max }$ for each type of plots suggest that the agricultural practices induce various changes to the soil hydraulic properties, as all plots were initially set up on the same soil. Even if other observations (discussed hereafter) qualitatively support this assumption, it has to be mentioned that simulated runoff and soil water storage are not very sensitive to this parameter, as the magnitude of runoff is mostly controlled by the surface storage capacity. Assuming a constant subsurface capacity for all farming practices would have conducted to a reasonable model fit.

As our model is based on the well-established FAO evapotranspiration model, a theoretical crop development is taken into account based on the typical duration of each development stage (affecting the value of the crop coefficient $K_{C}$ ). Hence, even if evapotranspiration can be re- 
duced or cancelled during water shortage, plants repeatedly exposed to dry spells are assumed to resume evapotranspiration at the same rate as if no stress had been experienced once water becomes available again. In reality, long or frequent water stress periods affect the plant development, as it has been clearly observed for the control and stone row plots. Actual evapotranspiration would be reduced compared to continuously well-watered crops. In our model, this weakness leads to an overestimation of the plant water requirements for the control and stone row plots once the crops have accumulated a development gap, thus potentially anticipating the start of dry spells and increasing their frequency.

The better hydrologic conditions provided by the farming practices are also clearly transcribed in higher crop yields during the three years. Table 5 shows the effective grain yield for each plot. We notice that crop yields are systematically higher in 2015 compared to 2016 and 2017, even if we could have expected increasing efficiency several years after the installation of the practices, as suggested by many authors (Zougmoré et al. 2003b, Barry et al., 2009, Bayala et al., 2011). Despite the late sowing and crop installation in 2015, the abundant and welldistributed rainfall has ensured the plant water demand even without the help of farming practices (Figure 8a). Only the half-moon plots have provided sufficient water storage in order to foil the recurrent water stresses observed in 2016 and to prompt higher yields than those observed in 2015. The harvests are also slightly better in 2016 than in 2017, except for the zaï plots. The rainfall amount of these years are similar, however the rainfall was more evenly distributed in 2016, especially during the early stage of the season. The first stress period occurs around 55 DAS in 2016, whereas water deficit is already observed after 22 DAS in 2017 (Figure 8 3 -b), which could have induced a detrimental development delay. In addition, Doto (2016) has shown that stress periods arising at the late season during the grain-filling period can strongly affect the grain yield, even when the plant development has not been disturbed. This is especially relevant in 2017, as after the rainfall event that has occurred 70 DAS, there was no further significant rainfall until harvest (Figure 8 c).

The grain yields shown in Table 5 give evidence of the efficiency of the agricultural techniques, as it has also been reported by Araya et al. (2015). Looking at each year individually, these results support the main outcomes of the hydrological assessment, with stone rows providing a slight improvement in terms of runoff reduction and soil water availability compared to the control. Zaï and halfmoon plots allow the mitigation of almost all dry spells by retaining water at the surface and strongly reducing runoff. However, it can also be noticed that securing water availability for the plants is not the sole benefit of these water harvesting techniques. Even when the rainfall amount seems to satisfy the plant water requirements without the need of farming practices like in 2015, the stone row, zaï and half-moon plots still provide a sizeable
Table 5: Millet grain yield on the experimental plots in 2015, 2016, 2017.

\begin{tabular}{lccc}
\hline & \multicolumn{3}{c}{ Grain yield $(\mathrm{Kg} / \mathrm{ha})$} \\
\cline { 2 - 4 } & 2015 & 2016 & 2017 \\
\hline Control & 252.5 & 176.3 & 164.2 \\
Stone row & 710.6 & 661.8 & 571.8 \\
Zaï & 1438.1 & 972.7 & 1091.4 \\
Half-moon & 1944.0 & 2177.3 & 1453.9 \\
\hline
\end{tabular}

increase in yields.

Several factors can explain the high yields of the water harvesting techniques in regards to the control. Indeed, also in 2015 when no significant water stress has been noticed even on the less efficient techniques, the grain yields were much higher for zaï and half-moons. However, in addition to providing better hydrologic conditions through a modification of the water balance, farming practices also allow to retain more efficiently the organic amendments that stay in their vicinity instead of being rapidly washed out (Zougmore et al., 1993, Zougmoré et al., 2004; Kiema et al., 2008). Avoiding this amendment loss could significantly raise the grain yield (Zougmoré et al., 2014, Suzuki et al., 2016). In addition, improving the soil moisture conditions and increasing the active soil depth (see Figure 6) can enhance root development and induce significant changes in soil physical, chemical and microbiological properties, eventually enhancing infiltration, aeration and soil nutrient availability. For example, Kaiser et al. (2017) have reported a large activity of termites in zaï fields. The furrows dig by the termites act as preferential flow pathways, hence drastically increasing infiltration. These feedback effects of farming practices on soil properties justify accounting for a technique-specific storage capacity in our model, as it has also been recognized by Soulis and Valiantzas (2012). The use of these techniques can in the longer term (usually five years) lead to the full restoration of soil and alleviate any further need of farming practices (Roose et al., 1995, Zougmoré et al., 2014).

In this study, some of these feedback effects of farming practices on soil properties have been detected, notably in the changes of measured saturated hydraulic conductivities or the enhanced termite activity on the zaï plots. The erosion crust that initially existed on each plot has persisted on the control and stone row plots, but seems to be averted by the presence of zaï pits that prompt higher hydraulic conductivities throughout the years. Nonetheless, even though half-moons have always come out as the best option both in terms of hydrological and agricultural performances, these slow changes induced by the technique appear to be more detrimental than favourable in the long run. Indeed, half-moon saturated hydraulic conductivities have decreased from year to year, and were the smallest of all experimental plots in 2017. In addition, a decantation crust develops during the rainy season inside the half-moons, and termite activity is strongly reduced 
(as reported by Fatondji et al., 2009). These changes may be attributed to the large retention capacity of the halfmoons, which can hold water during extended periods and may be more prone to clogging through the slow deposition of fine particles. Moreover, this ponding effect leaves the crop base immersed, which is likely to be harmful for the plants if immersion persists for too long. This may also explain the significant reduction of grain yield between 2016 and 2017, whereas those of the zaï plots show a slight increase.

It has been shown that the capacity to provide a water supply that meets the crop requirements even during dry spells is a prerequisite for a successful agricultural technique. However, the design and sizing of these techniques should be carefully adjusted to the local climatic conditions in order to provide this necessary supply at any time while avoiding the creation of adverse conditions in the longer term. In the future, more efforts will be needed in order to understand better the response of soil physical, chemical and biological properties to the hydrological conditions prompted by the nature of the water harvesting techniques.

\section{Conclusion}

The field experiments conducted in the Burkinabe Sahel have demonstrated the runoff reduction potential of water harvesting techniques, in particular zaï and halfmoons. The parsimonious model developed performed well at reproducing the observed runoff under different rainfall regime without recalibration between the seasons. It has also allowed providing an assessment of the soil water dynamics, which prove very different between the types of techniques, but also highly conditioned by the precipitation distribution during the growing season. Zaï and half-moons were able to sustain sufficient water available for the crops even during the longer dry spells, whereas stone row and direct sowing without any specific farming practice experience several days of dry storage leading to substantial plant water deficits at the end of bad seasons. Our model can be used as a decision-making tool to evaluate the performance of a variety of farming practices under different climatic regimes.

These farming techniques allow ensuring a constant water availability for crop, which obviously appears as a prerequisite for optimal plant development and for securing decent yields. However, our study also gave some insights on some other effects induced by the changes of hydrological conditions. Some of these outcomes seem to have immediate effects on crop health as the impediment of amendment leaching through runoff, but other operate on the longer term and can affect soil physical, chemical and biological properties. These feedbacks will require more attention in order to improve soil management under a climate change perspective and to propose optimize farming practices for specific contexts.

\section{Acknowledgements}

This research was carried out at the International Institute for Water and Environmental Engineering (2iE foundation) of Burkina Faso and at the Institute of Territorial Engineering INSIT, School of Business and Engineering Vaud (HEIG-VD), University of Applied Sciences, Switzerland. Financial support has been provided by the Swiss Agency for Development and Cooperation (SDC) [grant Projet 3E Afrique, Burkina Faso - 2iE, partie scientifique]. We are also thankful to the local communities in the Tougou watershed for their kind cooperation.

\section{References}

Allen, R.G., Pereira, L.S., Raes, D., Smith, M., 1998. Crop Evapotranspiration - Guidelines for Computing Crop Water Requirements. FAO Irrigation and Drainage Paper 56. Food and Agriculture Organization of the United Nations. Rome.

Araya, T., Nyssen, J., Govaerts, B., Deckers, J., Cornelis, W.M., 2015. Impacts of conservation agriculture-based farming systems on optimizing seasonal rainfall partitioning and productivity on vertisols in the Ethiopian drylands. Soil and Tillage Research 148, 1-13. doi 10.1016/j.still.2014.11.009

Assefa, S., Biazin, B., Muluneh, A., Yimer, F., Haileslassie, A., 2016. Rainwater harvesting for supplemental irrigation of onions in the southern dry lands of Ethiopia. Agricultural Water Management 178, 325-334. doi 10.1016/j.agwat.2016.10.012

Barbier, B., Yacouba, H., Karambiri, H., Zoromé, M., Somé, B., 2009. Human Vulnerability to Climate Variability in the Sahel: Farmers' Adaptation Strategies in Northern Burkina Faso. Environmental Management 43, 790-803. doi 10.1007/ s00267-008-9237-9

Barry, B., Olaleye, A.O., Zougmoré, R., Fatondji, D., 2009. Rainwater Harvesting Technologies in the Sahelian Zone of West Africa and the Potential for Outscaling. volume 126. IWMI.

Bayala, J., Kalinganire, A., Tchoundjeu, Z., Sinclair, F., Garrity, D., others, 2011. Conservation agriculture with trees in the West African Sahel-a review. ICRAF occasional paper 14.

BUNASOLS, 2015. Caractérisation Des Sols Du Site de Tougou. Technical Report. Bureau National des Sols. Ouagadougou, Burkina Faso.

Casenave, A., Valentin, C., 1989. Les États de Surface de La Zone Sahélienne: Influence Sur l'infiltration. Collections Didactiques. editions de l'orstom ed., Paris, France.

Da, C.É.D., 2008. Impact des techniques de conservation des eaux et des sols sur le rendement du sorgho au centre-nord du Burkina Faso. Les Cahiers d'Outre-Mer 61, 99-110. doi 10.4000/com.3512.

Danjuma, M., Mohammed, S., 2015. Zai pits system: A catalyst for restoration in the dry lands. Journal of Agriculture and Veterinary Science 8, 1-4.

Darcy, H., 1856. Les Fontaines Publiques de La Ville de Dijon: Exposition et Application... Victor Dalmont.

Diello, P., 2007. Interrelation Climat-Homme-Environnement Dans Le Sahel Burkinabé: Impacts Sur Les États de Surface et La Modélisation Hydrologique. SIBAGHE - Systèmes intégrés en Biologie, Agronomie, Géosciences, Hydrosciences et Environnement. Sciences et Techniques du Langedoc, Université de Montpellier II. Montpellier, France.

Doto, V.C., 2016. L'irrigation de Complement à Partir de Petits Bassins Individuels En Zone Sahelienne Burkinabé : Impact Sur La Production Des Exploitations Agricoles Familiales. Ph.D. thesis. Institut International d'Ingénierie de l'Eau et de l'Environnement.

Duponnois, R., Dia, A., 2013. La Grande Muraille Verte: Capitalisation Des Recherches et Valorisation Des Savoirs Locaux. IRD.

Esteves, M., Faucher, X., Galle, S., Vauclin, M., 2000. Overland flow and infiltration modelling for small plots during unsteady rain: 
Numerical results versus observed values. Journal of Hydrology 228, 265-282. doi 10.1016/S0022-1694(00)00155-4

Fatondji, D., Martius, C., Zougmore, R., Vlek, P.L.G., Bielders, C.L., Koala, S., 2009. Decomposition of organic amendment and nutrient release under the zai technique in the Sahel. Nutrient Cycling in Agroecosystems 85, 225. doi 10.1007/ s10705-009-9261-z

Fiedler, F.R., Ramirez, J.A., 2000. A numerical method for simulating discontinuous shallow flow over an infiltrating surface. International journal for numerical methods in fluids 32, 219-239.

Foglia, L., Hill, M.C., Mehl, S.W., Burlando, P., 2009. Sensitivity analysis, calibration, and testing of a distributed hydrological model using error-based weighting and one objective function. Water Resources Research 45.

Gerbaux, M., Hall, N., Dessay, N., Zin, I., 2009. The sensitivity of Sahelian runoff to climate change. Hydrological Sciences Journal 54, 5-16. doi 10.1623 /hys j.54.1.5

Ghasemi, A., Zahediasl, S., 2012. Normality tests for statistical analysis: A guide for non-statisticians. International journal of endocrinology and metabolism 10, 486.

INERA, 2011. Fiche Technique Variétale de Mil.

Jayaraman, K., 1999. Manuel de Statistique Pour La Recherche Forestière. FAO, European Comission and Netherland Development Cooperation. Kerala Forest Reseach Institute. Peechi, India.

Kaiser, D., Lepage, M., Konaté, S., Linsenmair, K.E., 2017. Ecosystem services of termites (Blattoidea: Termitoidae) in the traditional soil restoration and cropping system Zaï in northern Burkina Faso (West Africa). Agriculture, Ecosystems \& Environment 236, 198-211. doi 10.1016/j.agee.2016.11.023.

Keita, A., Yacouba, H., Hayde, L.G., Schultz, B., 2014. Comparative Non-linear Regression - Case of Infiltration Rate Increase from Upstream in Valley. International Agrophysics 28. doi 10.2478/ intag-2014-0020

Kiema, A., Nianogo, A.J., Ouedraogo, T., 2008. Effets des cordons pierreux sur la régénération d'un pâturage naturel de glacis au Sahel. Cahiers Agricultures, 281-288doi 10.1684/agr.2008.0204.

Kpadonou, R.A.B., Owiyo, T., Barbier, B., Denton, F., Rutabingwa F., Kiema, A., 2017. Advancing climate-smart-agriculture in developing drylands: Joint analysis of the adoption of multiple onfarm soil and water conservation technologies in West African Sahel. Land Use Policy 61, 196-207. doi 10.1016/j.landusepol. 2016.10.050

Mahé, G., Paturel, J.E., 2009. 1896-2006 Sahelian annual rainfall variability and runoff increase of Sahelian Rivers. Comptes Rendus Geoscience 341, 538-546. doi $10.1016 /$ j.crte.2009.05.002

Maïga-Yaleu, S., Guiguemde, I., others, 2016. Hydrochimie des eaux de pluie et de ruissellement en région Sahélienne Hydrochemistry of rainwater and runoff in Sahel region. Journal de la Société Ouest-Africaine de Chimie 42, 16.

Maïga-Yaleu, S., Guiguemde, I., Yacouba, H., Karambiri, H., Ribolzi, O., Bary, A., Ouedraogo, R., Chaplot, V., 2013. Soil crusting impact on soil organic carbon losses by water erosion. CATENA 107, 26-34. doi 10.1016/j.catena.2013.03.006

Maisharou, A., Chirwa, P., Larwanou, M., Babalola, F., Ofoegbu, C., 2015. Sustainable land management practices in the Sahel: Review of practices, techniques and technologies for land restoration and strategy for up-scaling. International Forestry Review 17, 1-19. doi 10.1505/146554815816006974

Mishra, S.K., Singh, V.P., 2003. Soil Conservation Service Curve Number (SCS-CN) Methodology. volume 42 of Water Science and Technology Library. Springer, Dordrecht, Netherlands. doi 10 . 1007/978-94-017-0147-1

Moriasi, D.N., Arnold, J.G., Van Liew, M.W., Bingner, R.L., Harmel, R.D., Veith, T.L., 2007. Model evaluation guidelines for systematic quantification of accuracy in watershed simulations. Transactions of the ASABE 50, 885-900.

Mounirou, L.A., Yacouba, H., Karambiri, H., Paturel, J.E., Mahé, G., 2012. Measuring runoff by plots at different scales: Understanding and analysing the sources of variation. Comptes Rendus Geoscience 344, 441-448. doi $10.1016 / j$.crte.2012.08.004

Mügler, C., Planchon, O., Patin, J., Weill, S., Silvera, N., Richard,
P., Mouche, E., 2011. Comparison of roughness models to simulate overland flow and tracer transport experiments under simulated rainfall at plot scale. Journal of Hydrology 402, 25-40. doi 10 . $1016 / \mathrm{j} \cdot \mathrm{jhydrol} .2011 .02 .032$

Niang, D., Mermoud, A., Yacouba, H., Ribolzi, O., 2012. Temporal evolution of the hydrodynamic behaviour of sandy deposits in the Sahelian part of Burkina Faso. Journal of Soil Science and Environmental Management 3, 297-307.

Perrin, C., Michel, C., Andréassian, V., 2009. A set of Hydrological Models (Chapter 16), in: Environmental Hydraulics. john wiley and sons ed.. J. M. Tanguy, Paris. volume 279 of ISTE Ltd, pp. 439-509.

Peugeot, C., Esteves, M., Galle, S., Rajot, J.L., Vandervaere, J., 1997. Runoff generation processes: Results and analysis of field data collected at the East Central Supersite of the HAPEX-Sahel experiment. Journal of Hydrology 188, 179-202.

Reij, C., Tappan, G., Smale, M., 2009. Agroenvironmental Transformation in the Sahel: Another Kind of" Green Revolution". IFPRI Discussion Paper 00914. International Food Policy Research Institute.

Rockström, J., Folke, C., Gordon, L., Hatibu, N., Jewitt, G., De Vries, F.P., Rwehumbiza, F., Sally, H., Savenije, H., Schulze, R., 2004. A watershed approach to upgrade rainfed agriculture in water scarce regions through Water System Innovations: An integrated research initiative on water for food and rural livelihoods in balance with ecosystem functions. Physics and Chemistry of the Earth, Parts A/B/C 29, 1109-1118.

Roose, E., Kaboré, V., Guenat, C., 1995. Le zaï, une technique traditionnelle africaine de réhabilitation des terres dégradées de la région soudano-sahélienne (Burkina-Faso), in: L'homme PeutIl Refaire Ce Qu'il a Défait ?. number 1994/11/14-19 in Congrès International sur la Restauration des Terres Dégradées, des Zones Arides et Semi-Arides, Tunis (TUN), pp. 249-265.

Sawadogo, H., Bock, L., Lacroix, D., Zombré, N.P., 2008. Restauration des potentialités de sols dégradés à l'aide du zaï et du compost dans le Yatenga (Burkina Faso). Biotechnologie, Agronomie, Société et Environnement 12, 279-290.

Soulis, K.X., Valiantzas, J.D., 2012. SCS-CN parameter determination using rainfall-runoff data in heterogeneous watersheds - the two-CN system approach. Hydrology and Earth System Sciences 16, 1001-1015. doi 10.5194/hess-16-1001-2012.

Suzuki, K., Matsunaga, R., Hayashi, K., Matsumoto, N., Tobita, S., Bationo, A., Okada, K., 2016. Long-Term Effects of Fertilizer and Organic Matter Application on Millet in Niger. Agronomy Journal 108, 873. doi 10.2134/agronj2015.0375

United States Departement of Agriculture, 1986. Urban Hydrology for Small Watersheds. Technical Report TR-55. Natural Resources Conservation Service, Conservation Engineering Division.

Woolhiser, D., Smith, R., Goodrich, D., 1990. KINEROS, A Kinematic Runoff and Erosion Model: Documentation and User Manual. Technical Report ARS-77. U.S. Departement of Agriculture, Agricultural Research Service.

Zongo, B., 2016. Stratégies Innovantes d'adaptation à La Variabilité et Au Changement Climatiques Au Sahel : Cas de l'irrigation de Complément et de l'information Climatique Dans Les Exploitations Agricoles Du Burkina Faso. Ph.D. thesis. Université de Liège. Belgique.

Zongo, B., Diarra, A., Barbier, B., Zorom, M., Yacouba, H., Dogot, T., 2015. Farmers' Perception and Willingness to Pay for Climate Information in Burkina Faso. Journal of Agricultural Science 8, 175. doi 10.5539/jas.v8n1p175

Zougmoré, R., Jalloh, A., Tioro, A., 2014. Climate-smart soil water and nutrient management options in semiarid West Africa: A review of evidence and analysis of stone bunds and zaï techniques. Agriculture \& Food Security 3, 16. doi 10.1186/2048-7010-3-16.

Zougmore, R., Kambou, N., Guillobez, S., 1993. Première approche de l'impact des ouvrages anti érosifs en pierre sur le ruissellement et les rendements en sorgho : Etude des écartement sur un bassin versant dans le plateau central, in: Gestion Durable Des Sols et Environnement En Afrique Intertropicale, Ouagadougou, Burkina Faso. pp. 278-283. 
Zougmoré, R., Mando, A., Ringersma, J., Stroosnijder, L., 2003a. Effect of combined water and nutrient management on runoff and sorghum yield in semiarid Burkina Faso. Soil Use and Management 19, 257-264. doi 10.1079/SUM2003199

Zougmoré, R., Mando, A., Stroosnijder, L., 2004. Effect of soil and water conservation and nutrient management on the soil-plant water balance in semi-arid Burkina Faso. Agricultural Water Management 65, 103-120. doi $10.1016 / \mathrm{j}$.agwat.2003.07.001

Zougmoré, R., Mando, A., Stroosnijder, L., Ouédraogo, E., 2005. Economic benefits of combining soil and water conservation measures with nutrient management in semiarid Burkina Faso. Nutrient Cycling in Agroecosystems 70, 261-269.

Zougmoré, R., Zida, Z., 2000a. Lutte Anti-Érosive et Amélioration de La Productivité Du Sol Par l'aménagement de Cordons Pierreux. Fiche Technique 1. INERA. Koudougou, Burkina Faso.

Zougmoré, R., Zida, Z., 2000b. Recupération Agronomique Des Terres Encroutées Par La Technique de Demi-Lune. Fiche Technique 8. INERA. Koudougou, Burkina Faso.

Zougmoré, R., Zida, Z., Kambou, F., 2000. Récupération Agronomique Des Terres Encroutées Par La Technique de Zaï. Fiche Technique 6. INERA. Koudougou, Burkina Faso.

Zougmoré, R., Zida, Z., Kambou, N., 2003b. Role of nutrient amendments in the success of half-moon soil and water conservation practice in semiarid Burkina Faso. Soil and Tillage Research 71 , 143-149. doi 10.1016/S0167-1987(03)00050-3 